\title{
The "New Turkey" Narrative and The Hegemonic Struggle of Justice and Development Party and Erdogan: A Gramscian Perspective (2002-2019)
}

Fethi Ufuk Özışık*

\begin{abstract}
The production of legitimacy and consent has always been among the main concerns and questions of political science. The political success of Erdoğan and the Justice and Development Party (AK Parti) is based on the progress made in the process of democratization and economic development policies as much as on their ability to align the popular masses with their political orientations and visions. In this perspective, firstly, the narrative of New Turkey presents itself as a discursive and strategic instrument and as a superstructural element. Secondly, this narrative contains ideological, cultural and normative elements in that the AK Parti uses it in its hegemonic struggle against the political and cultural elites of Old Turkey. Indeed, by adopting a perspective of analysis around the narrative of New Turkey, this work aims to focus on the emergence and evolution of this narrative according to the conjonctural and contextual changes. On the other hand, the focus will be on how the political power tries to embody this narrative in political, social and cultural fields through its various actions and policies.
\end{abstract}

Keywords: Justice and Development Party, New Turkey, Old Turkey, Native-National, Hegemony, Legitimacy, Ideology.

“Yeni Türkiye” Söylemi ve AK Parti ile Erdoğan'ın Hegemonik Mücadelesi: Gramscian Bir Perspektif (2002-2019)

Öz

Meşruluk ve rıza üretimi süreçlerinin incelenmesi siyaset biliminin temel araştırma konularından biri olmuştur. Türkiye'de 2002 yilından beri iktidarda olan Adalet ve Kalkınma Partisi (AK Parti) ve lideri Recep Tayyip Erdoğan, bu süre zarfında hem istikrarli bir ekonomik büyümeyi hem de demokratikleşme yönündeki reformları hayata geçirmede önemli başarılar elde etmiştir. AK Parti ve Erdoğan'ın, geniş halk kitlelerini kendi politika hedefleri ve yönelimleriyle iliş̧ilendirebilmesi de önemli bir başarı olarak görülmektedir. Bu bağlamda, siyasi iktidar "Yeni Türkiye" anlatısını söylemsel ve stratejik bir araç ve üstyapısal bir etken olarak kullanmaktadır. Yeni Türkiye söylemi ve bunun barındırdığı ideolojik, kültürel, normatif öge ve simgeler, Eski Türkiye ve onun elitleriyle girişilen hegemonya mücadelesinde kullanıma sokulmaktadır. Bunlardan hareketle bu çalışmada, Yeni Türkiye kavramının ortaya çıkış süreci, içeriği ve yaşamış olduğu konjonktürel dönüşümler ele alınacaktır. Bununla birlikte, siyasi iktidarın çeşitli eylem ve politikalarıyla bu söylemi siyasal, sosyal ve kültürel alanlarda nasıl somutlaştırmaya çalıştığına da odaklanılacaktır.

Anahtar Kelimeler: Adalet ve Kalkınma Partisi, Yeni Türkiye, Eski Türkiye, Yerli ve Milli, Hegemonya, Meşruluk, İdeoloji.

*Dr. Öğr. Üyesi | Marmara Üni., Siyasal Bilgiler Fakültesi Siyaset Bilimi ve Kamu Yönetimi Bölümü Ph.D., Marmara University, Faculty of Political Sciences, Departement of Political Science and Public Administration (French Program), istanbul, Turkey

ufuk.ozisik@marmara.edu.tr | ORCID:0000-0003-1633-5043 | DOI: 10.36484/liberal.894173

Liberal Düşünce Dergisi, Yıl: 26, Sayı: 102, Bahar 2021, ss. 215-240.

Gönderim Tarihi: 10 Mart 2021 | Kabul Tarihi: 15 Haziran 2021 


\section{Introduction}

Initiated by American political scientist Emery Roe (1994), policy narrative analysis emphasizes the role of ideas in driving and changing public policy in helping political elites to act in situations of uncertainty, to simplify the reality in order to identify objectives and programs of action. Public policy narratives can be defined as: "less incantatory and normative than ideology, public policy narratives are scenarios that are less about what should happen than what will happen - according to the narrators - if events occur or situations change as expected. Even when their veracity is in question, these narratives are, explicitly, more programmatic than myths, and are intended to make their receivers internalize them and do something about them" (Roe, 1994: 37). In addition, the narrative of a public policy fulfills a persuasive and performative function as regards the acceptance of a program of action that underlies it. Public policy narratives "thus make social problems understandable and accessible to human action. Typically, they suggest a series of actions rather than others, linking the present to the future" (Radaelli, 2000: 257).

The New Turkey... A political/policy narrative? A discourse? A social construction? A project, a vision? A restoration or a revolution? It would be possible to go further in thinking about this notion that has become a phenomenon in Turkey since its first use by the Justice and Development Party (Adalet ve Kalkınma Partisi - AK Parti) and its leaders in 2013. We consider it as a narrative which aims to strengthen the political and cultural hegemony (as a gramscian conception) of the AK Parti and the conservative classes. As a policy narrative, its can also be considered as a référentiel by legitimizing the change in various public policies (Jobert \& Muller, 1987). In fact, the "New Turkey" ("Yeni Türkiye"), represented, designed, and mobilized by the AK Parti and Erdoğan brings together many political, social and economic elements. The notion has a political essence because it opposes the Old Turkey ("Eski Türkiye"), by devaluing it through its democratic failures: The culture of military tutelage mobilized by an army as a defender of the secular regime, the mistrust of a state elite vis-à-vis the elected representatives of the people and the demands for social changes. It is also about social dynamics because it represents the rise of a new conservative middle class in the face of the secular bourgeoisie, and on the other hand it represents a new "spirit" of the social state which defines itself as the servant of disadvantaged social groups. It contains political elements insofar as it relies on a certain process of democratization that has been going on since 2002. The notion is all the more conceived from an economic perspective if we look at the major 
infrastructure and transport projects or the economic development goals of 2023, 2053 or 2071, the centennials of the great moments of Turkish history.

Since the first use of the term "New Turkey" by AK Parti leaders in 2013, there has been enough time to make a more detailed analysis that could reveal the nature and the characteristics of this notion by considering the political, economic and international contexts that have certainly determined its evolution and meanings. It is important to place the New Turkey narrative in this line of events and political processes. The narrative thus becomes sensitive to important political developments and adapts its form as well as its substance to enlarge its legitimizing functions and capacities in political orientation and political decisions. As a result, the New Turkey narrative offers various assets to the government. By using this narrative, political power manages to stabilize the uncertainties related to changing contexts. Secondly, by its projections and its motivations for the future, the political power uses it to convince public opinion about the implementation of public policies and foreign policy decisions that would provoke reticence or important criticism besides public opinion.The construction of a large presidential palace, the realization of giant projects of construction or infrastructure representing phenomenal costs or the adoption of the presidential system in 2017, and military interventions in northern Syria since 2016 are not exempted from the legitimacy carried by the New Turkey narrative. And finally, this narrative also contributes to strengthening the discursive power of the AK Parti cognitively and ideologically in its hegemonic struggle against the "Old Turkey", a struggle that takes place as much in a political dimension as in the social, cultural and symbolical ones.

It is also important for us to highlight the main features of political polarization in Turkey in a historical perspective. Understanding the New Turkey narrative can not be possible without reference to the hegemonic struggle of two major political camps in the country.

\section{The New Turkey Narrative as a Tool in Hegemonic Struggle: A Gramscian Perspective}

Most of the articles and studies on recent political developments in Turkey, especially since Gezi protests, that focus on AK Parti policies choose to take a very critical stance towards the current regime. Considering actual government as an authoritarian, populist regime or as a dictatorship and in the meantime praising the "democratic forces" of the opposition figure explicitly in most of these works. Furthermore, our aim is not to delegitimate scientifically 
these works or open a debate with them. Indeed, in this article, beyond an effort of a categorization or a political judgement, the main interest would be to display the nature and evolution of the discourse and political orientations of the AK Parti and Erdogan through their usage of the New Turkey narrative. To do this, we have tried to concentrate on concrete facts while having the necessary care to maintain a certain political and ideological neutrality. In this regard, this work is based on a descriptive approach. This descriptive approach will consequently allows us to make an analytical approach. It is in this perspective that the adoption of the notion of hegemony in a gramscian sense takes on its full meaning.

Gramsci believed that the leading role of the dominant class must include ideology and consciousness, that is, the superstructure. The location of cultural, ideological, and intellectual variables as fundamental for the proletariat in its struggle to become a leading class is Gramsci's main contribution to Marxist theory. With it, Gramsci sought to undermine the economic determinism of historical materialism. He was acknowledging that human beings had a high degree of agency in history: human will and intellect played a role as fundamental as the economy ${ }^{1}$.

Cultural hegemony is most strongly manifested when those ruled by the dominant group come to believe that the economic and social conditions of their society are natural and inevitable, rather than created by people with a vested interest in particular social, economic, and political orders. Gramsci developed the concept of cultural hegemony in an effort to explain why the worker-led revolution that Marx predicted in the previous century had not come to pass. Central to Marx's theory of capitalism was the belief that the destruction of this economic system was built into the system itself since capitalism is premised on the exploitation of the working class by the ruling class. Marx reasoned that workers could only take so much economic exploitation before they would rise up and overthrow the ruling class. However, this revolution did not happen on a mass scale (Cole, 2020).

Gramsci emphasizes in particular the production of an alternative political, social and cultural hegemony alternative to that of the ruling class that would give ideological and motivational substance to revolutionary political movements. This approach refers to a critique of the classical Marxist model in that it further values the struggle that should be waged in the superstructural level. In fact, it is a vision that, without neglecting the capacity and the "material and physical” strengths of the labor movement (in the Italian context),

1 https://notevenpast.org/gramsci-on-hegemony/ (Juan Carlos de Orellana, “Gramsci on Hegemony") 
underlines the inescapable importance of an upward ideological struggle in the social, cultural and intellectual fields. Complete achievement and maintenance of power would not be possible without overthrowing the social and cultural hegemony of the ruling class. In this perspective, the use of force is not the only way to acquire state power. Without overthrowing the cultural hegemony of the ruling class by fabricating a competing civil society, a new ideology, a new universe of meaning, emotion, values and social motivations, the conquest of state power would be unsuccessful. Indeed, to achieve this, Gramsci empowers the dominated groups to produce its own civil society that should compete and then surpass the cultural hegemony of the ruling class. And according to Gramsci, this emerging civil society can not be constituted and driven without the ideological and socio-political support of the organic intellectuals intrinsic to the revolutionary movement.

Inspired by Gramsci's theoretical framework, an important question can be announced more concretely. To what extent can these Gramscian approaches be applied to the political and cultural antagonism that can be observed in the 21st century Turkey? Is it possible to bring together the pious part of the population, the so-called conservative bourgeoisie, and the various social, political and institutional partners of the latter in a whole, categorizing them as "dominated classes" of Old Turkey in the Gramscian sense of the term? And on the other side, is it possible to identify the Republican People's Party (Cumhuriyet Halk Partisi - CHP), the Kemalist army, the secular bourgeoisie and the different social, intellectual and political partners of the latter as "a dominant class $^{2 \text { "? }}$ This interrogation represents many nuances and demands a careful analysis insofar as in Turkey, we are already far enough from an antagonism between the "bourgeoisie" and the "proletariat". It can be considered that, in Turkey, political and even economic cleavages crystallize not particularly in the economic field but more specifically in the fields of ideology, culture and values. Among the social categories described above, the general principles of the capitalist economic system are not disputed by the secular part or by the conservative part of society, two social categories that we prefer to consider as two opposing political camps of Turkish political life. It is possible to remember that even in the first National Assembly (Birinci Meclis - 1920) before the foundation of the Republic, the main political divisions were divided between devletçi-seçkinciler ("statist and elitist" group as Birinci Grup in

2 Prof. Hasan Bülent Kahraman describes this alliance as a "historical bloc" (tarihsel blok) in a gramscian sense. This historical bloc was constitued by the army, the bureaucracy and the secular and Kemalist intellectuals (ordu-bürokrasi-aydınlar) during the first decades of Turkish Republic. (Kahraman, 2008) 
the First National Assembly) and the gelenekçi-liberaller ("traditionalist and liberal” group such as İkinci Grup). These two appellations contain two different worlds of meaning: Elitism refers in particular to a conception of state where the bureaucratic and military apparatus, that is to say an administrative elite, should dominate "the" political sphere and effectively delimit the governments elected by the people whose traditional values are constantly denounced as "archaic" and not compatible with the "modernist and Western" orientation of the new Kemalist regime. Statism also refers to a certain type of statist capitalism in which a "new" national and secular bourgeoisie should be created and supported by the state. This bourgeoisie should adhere to the new values and principles of the Republic: Secularism, modernism, Westernization and others. Statism covers all social, cultural, intellectual or educational life by empowering the central state in the regulation of social, public and cultural space with a top-down and unitarist logic. The challenge is to create a "new nation" through its new culture, its new alphabet, and thus its new conception of the "public" and its new secular values. And all this by reducing Islam to its sole individual practice and excluding all other social functions of religion from the public space. Whereas, tradition and liberalism refer to a political, social but also economic stance that firstly denounces the top-down approach and authoritarian practices of these new state elites. In this perspective, according to the gelenekçi-liberaller the new regime should alleviate its radicalism vis-à-vis the "tradition" by its cultural, social and even institutional orientations. On the political and institutional level, brutal breaks such as the abolition of the Caliphate or even the decision-making procedure followed for the declaration of the Republic are often criticized by these political actors. On the cultural level, mistrust of the adoption of the Latin alphabet or the choice of a model of secularism that is allergic to Islam represents some other challenges of this political camp. More specifically, liberal traditionalists envisioned a less authoritarian but more inclusive modernization process. As well as on the economic plan, this political camp took a more liberal approach in the Anglo-Saxon sense of the term, by seeking to minimize the role of the state in the economy and thus its interventionism.

The identification of the historical origins of political and ideological cleavages between the New Turkey (Yeni Türkiye) designed and developed by

3 This dualistic approach of Turkish political antagonism was proposed by Professor Emre Kongar. Kongar considers the statist and elitist camp as the founders and defenders(composed by civil and army bureaucracy) of republican and laic regime and its secular values. On the other hand, traditionalist and liberal camp is represented by provincial elites relying on religious and feodalistic values. According to Kongar, AKP is a follower of Democrat Party (Demokrat Parti), Justice Party (Adalet Partisi), Motherland Party (Anavatan Partisi) so all considered as the representatives of traditionalist and liberal camp. Whereas CHP is a part of statist and elitist camp (Kongar, 2016). 
the AK Parti and the Old Turkey (Eski Türkiye) is important. Such a perspective allows us to observe the roots of this political antagonism. In fact, these historical facts still determine the dynamics of contemporary political-cultural polarization. This historical perspective could go even further by making references to the Tanzimat era (1839) or to the periods of the Constitutional Monarchy $(1876,1908)$ in the Ottoman Empire. The political and ideological debates and cleavages of this period, where the main interest of politicians and intellectuals were the "survival of the Empire" in one way or another, have certainly determined and fueled the ideological struggle of these two political camps. A struggle whose origins can be traced back to the 19th century and a struggle that is far from being finalized even in 21st century.

In this perspective, the first chapter will focus on the temporal and strategic aspects of the New Turkey narrative according to the political, economic and international contexts which affect its content and orientation since 2013. In this perspective, the focus will be on the role of the different contextual variables which determine the orientation and the reconfiguration of this narrative. In this sense, the analysis will examine the political alliances and political decisions that are strongly interacting with the legitimacy produced by this narrative. Within the framework of our gramscian perspective, in the first chapter, the objective will be to highlight the emergence and evolution of political and social alliances led by AK Parti and Erdoğan. To what extent and how are the AK Parti's political alliances formed since 2002? Is this the emergence of a new historical bloc led by AK Parti and Erdoğan against the elites of Old Turkey? The second chapter will focus on a more descriptive analysis which will aim to focus on the role played by President Erdogan and the pro-AK Parti media in the diffusion of New Turkey narrative. Secondly it will emphasize especially the translation of this narrative to social, cultural and symbolical fields in the context of hegemonic struggle. Indeed, it aims to question the symbolic, cognitive and substantial aspects of New Turkey narrative, beyond its political and strategical orientations. In the concluding part, the objective will be to question the functions and capacities of the New Turkey narrative. We will show that the AK Parti and Erdoğan instrumentalize strategically this narrative on several dimensions in order to gain advantages in its hegemonic struggle. Attention will also be paid to the limitations and weaknesses of this narrative. 


\section{The New Turkey Narrative: A Tool of Political Strategy and a Legitimacy Instrument Sensitive to Contextual Changes}

In this first chapter, the aim will be to present the emergence and evolution of the New Turkey narrative according to several contexts which determine its substances and its orientations. Certainly, several political issues play a determining and decisive role in the evolution of the narrative. Therefore, the contextual facts will have important repercussions at the substantial dimension of the New Turkey narrative.

The Emergence of New Turkey Narrative - First Episode 2002-2016: The "New Turkey" as a Consequence of Democratization Reforms and Political Alliances

Following the first use of the term "New Turkey" in 2013, AK Parti leaders constantly refer to progresses and achievements made during the first ten years of their government to give meaning to this notion. This is why we have chosen to consider the period of 2002-2016 as the first phase and as the emergence of this "New Turkey". Furthermore, we consider that the first phase ends with a large-scale crisis which is the coup of July 15, 2016.

The AK Parti governments, since 2002, have carried out various political, democratic, economic, social, and institutional reforms. Certainly, the frequency and intensity of these reforms have been characterized and altered in different contexts and political strategies, obviously connected with the processes of political competition. The reformist character of the AK Parti governments has attracted growing support from a fairly diverse electorate bringing together the popular classes, conservatives, nationalists, emerging Anatolian bourgeoisie, various groups of businessmen as well as some of liberal-democrats. The latter, until recently, more precisely until the Gezi protests $^{4}$ (2013), have provided to the AK Parti a strategic support that nurtured its legitimacy among Kemalist voters and senior civil and military bureaucracy, anxious to preserve the secular and democratic character of the state. The support of these liberal democrats, -mostly from the revolutionary leftist movements of the 1960s and 1970s, was also a significant source of legitimization alongside the European Union and other international forces as

\footnotetext{
4 A wave of demonstrations and civil unrest in Turkey began on 28 May 2013, initially to contest the urban development plan for Istanbul's Taksim Gezi Park. (...) Subsequently, supporting protests and strikes took place across Turkey, protesting a wide range of concerns at the core of which were issues of freedom of the press, expression, and assembly, as well as the alleged "political Islamist government's erosion of Turkey's secularism.” (https://en.wikipedia.org/wiki/Gezi_Park_ protests)
} 
the United States. Furthermore, during the first mandates of the AK Parti, a concept entitled "The Second Republic" ("Ikinci Cumhuriyet") was mobilized by those liberal democrats ${ }^{5}$, praising the reforms of the AK Parti that finally allowed it to provide the Republic with a "democratic character".

Political legitimization changed course after the Gezi protests. The support of some liberal democrats declined and even many of them have become fervent opponents of Erdogan's regime, now described as "authoritarian". During that break, some representatives of AK Parti also indicated that they would continue to not align with the guidelines of these liberal democrats and their legitimacy would be based more on values and aspirations of the nation called "millet" and/or national will ("millî irade"). In this sense, following this political rupture in that first alliance, it is possible to admit that the AK Parti sought to consolidate its power by relying on a more populist discourse. Indeed, the AK Parti, having consolidated its power and electorate, following many political struggles against the military tutelage and against its illegal components (the trials of Ergenekon and Balyoz etc.), had to eliminate some of its political partners highlighting a political discourse less consensual but more exclusive. The AK Parti started to favor traditional, local, nationalist, and religious values that referred especially to the legacy of the glorious past of the Ottoman Empire, and to touch the subconscious of Turkish society which always expects a country that would become a regional or even international economic force. According to the AK Parti, this would be possible by revitalizing the values and symbols of the past and rejecting the political and societal alienation caused by the authoritarian policy of Westernization implemented since the Tanzimat reforms (1839) and continued more radically by the Kemalist regime.

Indeed, the first years of AK Parti governments, especially until the protests of Gezi, were characterized by the promotion of democratic and liberal values in the face of bureaucratic and military opposition but also against the Kemalist ideology carried by the CHP and its electorate as well as by a broad intelligentsia. In that context, the strategy of the AK Parti was to collaborate with liberal intellectuals but also with international actors like the European Union. Indeed, the legitimacy was fueled and reinforced by quite diverse actors. Democratization and Europeanization have not only been elements of the political discourse but they are also reflected in many public policies and many democratic and structural reforms. In this perspective, one of the the greatest democratic ambition was the resolution process (Çözüm Süreci)

5 https://www.hurriyet.com.tr/iste-2-cumhuriyet-takiminin-tam-kadrosu-7360946 
of the Kurdish problem officially declared in 2013, whose origins go back to Erdoğan's speech made in Diyarbakir in 2005. The resolution process with the Kurds presented itself as a crucial element of the New Turkey narrative.

\begin{abstract}
“(...) Until AK Parti governments, the main political approach was as follows: "The survival and the interests of the state are of paramount importance, the society's preferences are of secondary importance. (...) Our Sunni brothers, Alevi brothers, Christians, Jews, all minorities, various political and ideological groups, writers, artists, thinkers... These people have suffered because the system has chosen not to listen to societal demands... (...) the state is constantly afraid of freedom, the status quo has always wanted to avoid change, the regime perceived the change as a threat to its existence. A small minority which was supported and promoted by the state, the regime and the status quo, could lead a prosperous life and increase his wealth while the masses were despised... (...) Before we came to power in 2002, political stability does not exist. Once per 16 months, the country was brought to elections. In such countries, stability and trust cannot exist. Especially if during the 12 years of our power, the Old Turkey's actors were not so resisted to the dynamics of change, the country would have been much developed... Old Turkey was perceived as an obscure Turkey for the majority of the population, except elitists and mafia gangs that had surrounded the state. We all have suffered. Today, I am pleased to declare to you that the Old Turkey no longer exists. The state is now conscious of the dynamics and change requests."
\end{abstract}

These extracts are from a speech that was made by Erdogan in July 2014 during his presidential campaign. It is possible to see the establishment of a narrative: a narrative that represents a logical and discursive practice, a narrative that leads the reader or spectator to recognise the differences between the past and the present situation, a moral stance since it sets up a critical assessment of the past and the eventual values of the present and the future, a strategic and visionary narrative that precises the preferences and objectives of a new regime.

The same contents can be observed in many speeches of Erdogan but also in those of different political actors of the AK Parti. These are repetitive speeches that take place in different spaces; political forums, televised speeches, interviews with journalists, electoral meetings etc. The challenge is clear and obvious. The aim is to create a negative imaginary of the past during which democracy and economic development were paralyzed by the mistakes of the Kemalist regime and ideology. Secondly, the focus is on the benefits of the governments of AK Parti. AK Parti is defined as "the savior" of the masses who were despised until recently, and as the reformer of a corrupted political system which is diverted of its own origins. In this sense, the New Turkey means a renunciation of the past, and a transition to a new regime that would be more democratic, more efficient, more prosperous, and more liberal in economic sense and egalitarian in social terms. 
The first speech made by Ahmet Davutoglu, who had become the new Prime Minister and the new leader of the party in the AK Parti's congress held in August 2014, allows us to observe the pillars and main objectives of the New Turkey:

(...) We are ready for the great march of the New Turkey. The psychological basis of the New Turkey is self-confidence. In 12 years, many and great revolutions were made in the policies of transportation, health, agriculture, foreign policy... This success is based largely on the self-confidence of the Turkish nation. (...)The first pillar of the New Turkey is the self-confidence. (...) Secondly, New Turkey will be based on socio-cultural integration. This shall be achieved with the process of resolution of the Kurdish problem which is defined as the "resolution process". (...) The third restoration targets the political system. In the New Turkey, the government and the state are the servants of the nation. The democratization of the political system can be completed with the drafting of a new Constitution which even exceeds the standards of the European Union. Fourth, we have worked for the ending of bureaucratic-military tutelage over elected politicians. New Turkey will be governed not by bureaucratic, juridical and military elite but by the people and its representatives. Fifth, the restoration aimed values and moral foundations of the regime. We sought to build our power on transparency and on a style of government that cares about justice and equality. (...) Sixth, the New Turkey must restore its judicial system that had often the tendency to produce a juristocracy. Seventh field of restoration is that of our culture and civilization. (...) Eighth field of restoration is obviously that of the economy that would provide the necessary means to achieve the objectives set out above. And finally, the ninth restoration will concern foreign policy by strengthening Turkey's status in the international arena. (...) "(The first speech made by Ahmet Davutoglu, -who became the new Prime Minister and the new leader of the party in AKP's congress held in August 2014. *Davutoğlu's government ruled until 2016 before the nomination of Binali Yildirim as prime minister by President of Republic, Erdoğan)

It is possible to admit that these speeches made by Erdogan and Davutoğlu in 2014 are quite representative of the conception developed around the notion of New Turkey by the two leading AK Parti leaders of the time. We can see that both speeches contain elements that affirm the struggle -still in progress- against Old Turkey, and that promote and envisage the continuation of democratic reforms. 
The New Turkey Narrative, Native and National (Yerli ve Milli) (2016-2019) - A Rupture or a Second Episode? Impact of the Failed Coup (15 July 2016) and the alliance with the Nationalist Movement Party (Milliyetçi Hareket Partisi - MHP)

It must be remembered that the year 2013 was marked by the Gezi protests and the trials of 17-25 December, the manipulative judicial operation carried out by the Gulenist organization against the government. Erdoğan's position and reaction to the Gezi movement and the Gulenist parallel state (Paralel Devlet Yapılanmass - PDY) operation provoked various political reactions. First, the majority of liberal intellectuals who had previously supported the AK Parti changed sides by denouncing and severely criticizing Erdoğan's “authoritarian drift”. Secondly, the government's methods of repression served more to reinforce discontent among the secular segments of the population and to fuel political polarization in the country. Thirdly, in the AK Parti, the first big cracks between Abdullah Gül (and some other members of the party) and Erdoğan began. At the same time, it was in 2013 that the "resolution process" (Çözüm Süreci) of the Kurdish problem was declared and that the negotiations were started between Öcalan, the PKK and the government. It should be remembered that on the one hand in July 2015, Erdoğan declared the freeze then the decisive end of the resolution process, and that on the other hand in 2016, following his political disagreements with Davutoğlu he replaced the latter with Binali Ylldırım as the prime minister. Among the democratization reforms, the peace process with the Kurds had also played a significant role in extending the political and social hegemony of the AK Parti. The sudden end of the resolution process, the unexpected results in the elections of June 7 (2015) followed by the intensification of the fight against the Gulenist parallel state had irreversible effects on the discourse and the political strategy of the AK Parti and Erdoğan.

The period following these political events was marked by a reconfiguration of the political discourse of Erdoğan and the AK Parti. It seems that Erdoğan chose to interpret these political events as an "aggression" to the unity of the nation and the state. In this perspective, gradually, the inclusive, all-encompassing and consensual nature of the New Turkey narrative has drifted into a more exclusive and antagonistic stance, a stance that national and international opponents have denounced as "authoritarian drift". This "authoritarian drift" is related to a supposed policy of stigmatization and disqualification of opponents as "enemies" of the nation. Peoples' Democratic Party (Halklarm Demokratik Partisi - HDP) with its incessant support for the PKK, the CHP which explicitly supporting the Gezi movement and implicitly the Gulenist Parallel State organization, and many other components of the 
political opposition began to be considered as "threats" or "dangers" against the unity of the nation and the state.

The failed Gulenist coup (15 July, 2016) particularly accentuated the distancing of the government vis-à-vis the Western countries, in particular the European Union (EU) and the United States (USA), but also vis-à-vis the political opposition led by the CHP because of their implicit and sublime support for the Gulenist coup. The failed coup has also brought about changes in the AK Parti's political alliances. Devlet Bahçeli (the leader of the MHP) shortly after the failed coup appealed for a referendum on the adoption of the presidential system. As a result, the AK Parti in line with this MHP proposal submitted this constitutional change to the referendum and Turkey adopted the presidential system in 2017, entitled “Cumhurbaşkanlığ Hükümet Sistemi”. However Erdoğan, following the Gezi protests and the Gulenist plots, was looking for new political alliances. One must consider the MHP's grip on constitutional change from this perspective. The alliance formed between the MHP and AK Parti during the referendum in 2017 has since been formalized as "Cumhur Ittifakı (People's Alliance)" during the Erdoğan's campaign for the 2018 presidential elections. Since then, it is possible to admit that the government has no longer been able to pursue a program of political action promoting reforms on democratization or on solving the Kurdish problem. In fact, the MHP is an ally that does not hide in any way its allergy to such types of political reforms. Moreover, it should be remembered that Erdoğan had already set the course for a nationalist and populist discourse since Gezi. He had qualified the survival of the state ("devletin bekası") as a political priority against the enemies of the nation such as the Gulenist terrorist organization (Fethullahçı Terör Örgütü - FETÖ) and against the Kurdish separatism explicitly supported by the United States in the northern Syria. The political alliance with the MHP accelerated this nationalist and statist approach by the AK Parti.

Another reason of this shift is of an economic nature. The destabilization of the Turkish economy of the last years seems to incite the government to develop a discourse revalorizing a certain statist interventionism referring to the notion of "economic independence". Important developments in the military industry sector or in the energy sector show us that this approach is implemented in a concrete way. Moreover, since the failed coup of July 15, 2016, Turkey's relations with Western countries, particularly with the United States and the European Union, have become increasingly tense and conflictual. Erdoğan continues to denounce the implicit and / or explicit support of the United States and some of European Union (EU) countries 
such as Germany and Greece for the Gulenist terrorist organization. On the other hand, the military operations started in northern Syria by Turkey (Firat Kalkani-2016, Zeytin Dalı / Afrin-2018 / Barış Pınarı-2019) to fight the Syrian branches of the PKK near its borders have caused quite negative reactions to the United States. There are also disagreements between Turkey and the EU and some other countries like France, Greece and Israel, over the recent maritime operations of Turkey to carry out hydrocarbon research activities in the Eastern Mediterranean Sea. In this perspective, we can admit that the politico-economic context and the international conjuncture have certainly led the AK Parti to develop a more defensive and reactionary strategy in the face of various dynamics destabilizing its power. It is from this international and economic context that the AK Parti's political alliance with the MHP makes sense. The MHP, by its nationalist, statist and pro-security approaches, fiercely supports the aggressive and patriotic policies of Erdoğan in the fields mentioned above. Indeed, if the AK Parti receives the explicit support of the MHP this is not without consequences on the nature of New Turkey narrative.

According to this highly destabilizing political, economic and international context, for the AK Parti and Erdoğan it is therefore necessary to produce new arguments of legitimacy and consent. The political and international context after the failed coup is quite different from that before 15 July 2016. Indeed, the New Turkey narrative has also led to the seizure of new content or even new ideological orientations. It is in this perspective that one must study the gradual rise of new forms of populist discourse referring to the history and glorious past of the Ottoman Empire - without forgetting to make "brief" references to Atatürk-, to the religious and traditional values, but also to the great potential of the country which would be "victorious" again by taking inspiration from its traditions and its "native and national" (yerli ve millı $\imath^{\natural}$ characteristics in the near future. Indeed, the modified version of the New Turkey narrative is distinguished from the original version by its connotations further promoting nationalist and conservative values. While

6 In this study, we did not prefer to enlarge the historical, intellectual and ideological origins of these terms, Yerli ve Milli used especially by conservative-nationalist intellectuals in Turkey. We consider that it must be the subject of another detailed research paper. Meanwhile, Tanıl Bora's article (Bora, 2017) untitled, “Conservative Nativist Narrative” ("Muhafazakâr Yerlilik Söylemi”) can be suggested for a deep understanding of these terms. Cemil Meriç, Ahmet Kabaklı, Peyami Safa and İsmet Özel could be included amongst principal conservative intellectuals who have used of these terms. Above all, their main effort was the promotion of traditional, native and conservative values against the preponderant secularist and westernization values mainly brought about by Kemalist elites and establishment. Indeed, we consider that the AK Parti's use of these terms largely aligns with the vision of these intellectuals. The native and nationalist character of the New Turkey's political regime constitute also a new raison d'Etat by replacing westernization values and policies dictated by Kemalist elites. Furthermore, the term of "millî" implies especially the defense of state's survival (beka) and national unity against internal and external enemies. 
the first version implied more the development of the democratic character of the state and provided a culture of deliberative democracy between the latter and different components of society, this modified version of the post-July 15 rather contains statist and nationalist elements (Aslan, 2018) by a tendance of reducing several components of political opposition to a threat against national interests or even to "domestic branches" of foreign enemies.

According to Ali Aslan, until the elections of June 7 (2015), the AK Parti put forward its politics of "civilization" (Medeniyet Siyaseti). The policy of civilization envisaged the integration and the cohesion between the different components of the society by making reference to the Islamic values, to the Ottoman and Seljuk Empire's legacy against the secular and nationalist identity promoted by Kemalism. This approach, in order to discredit any policy of polarization (kutuplaşma siyaseti), relies on the integration of different and various components of the Turkish society. While through the "native and national" politics (Yerli ve Milli Siyaset), the aim is to weaken all the elements resisting to the process of democratization in Turkey. According to Ali Aslan, all these two approaches are based on conservative and pious components of the Turkish society which, henceforth, have become irreversible political subjects under AK Parti governments. The politics of civilization consisted in empowering these social classes as leading political actors. Meanwhile, the native and national politics are mainly concerned with preserving this role played by these political subjects against internal and external threats and dangers. Indeed, the politics of civilization and the native and national politics are complementary insofar as both approaches have the objective of creating and preserving a social integration and cohesion around a "reconsidered" national identity (Aslan, 2018: 95-103).

We choose to consider this evolution of the New Turkey narrative towards a more statist and nationalist posture not as a brutal break with its first conception and usage but as a "necessary" reorientation. Obviously, Erdoğan and the other AK Parti elites did not make such a break in their speeches.

"The new "native and national" consensus calls for covering all components of society. This new consensus will not be based on communitarianism, will not privilege any ideological affiliation and will not favor any affiliation to a certain elite or to a sect or to a religion. (...)The concepts of "native" and "national" have the potential to include all components of society by a democratic and egalitarian way in the functioning of the political system and in the political culture. So these concepts are capable of designating the ideological character of New Turkey. (...) Indeed, the concepts of "native" and "national" have this capacity to unite us all under one roof respecting all of our differences and particularities" (Esayan, 2016) 
In this logic, the New Turkey narrative is not abandoned in its entirety. But following the decisive contextual changes, this one has to be adapted to the new political, strategic and economic conditions.

\section{The New Turkey Narrative: Investments of the AK Parti and Erdoğan in the Socio-Cultural Fields}

In this second chapter, the objective will be to focus on the hegemonic aspects of the New Turkey narrative. The role played by Erdoğan, the emergence and spread of pro-AK Parti media as well as the achievements observed in the social and cultural fields will be presented and discussed.

In fact, a question must be asked at this point: What do we mean precisely by the term "New Turkey"? What does this notion represent in the political, cultural, symbolical and ideological dimensions? And more importantly, if we could consider the New Turkey narrative as an element of the hegemonic struggle, how does its construction occur?

\section{Erdoğan's Role and Impact}

In Turkey, it is possible to admit that the domination of the public space (kamusal alan) by the state, relying on a tradition of bureaucratic administration, has prevented the development of a civil society of the Western type. It is true that the control and regulation of the public space is a policy exercised not only by the administrative elites defending the Kemalist ideology but also by the governments elected in one way or another. Erdoğan and his governments are not exempt. For those who hold state and institutional power in Turkey, it has always been crucial to model the public space. The diffusion and / or imposition of dominant values to the masses ("halk" according to the Kemalists, "millet" according to conservative political parties) has never ceased to be applied by the holders of state power.In this sense, the strategy of Erdoğan and the AK Parti is composed by multiple modes of action.

Erdoğan can be described as a speaker par excellence by his training in a high school of Imam-Hatip and his own ability to raise awareness and electrify the masses. So, Erdoğan's first modality of action is to appear on every occasion in front of multiple types of "spectators" in many platforms. Sometimes he quotes a poem sometimes he takes up his position of "religious man" by making references to the Koran. Or, he becomes the "first commander" of the army making use of military concepts and expressions. And for a while, he tries to influence business circles by taking over the role of an expert in finance and economics. Indeed, far from making a caricature, it is a question 
of paying attention to one of the most influential strategies of the charismatic leader, that of reproducing his charismatic domination by constantly strengthening his relations with all the components of society and continuously developing political communication. If it is the form, the substance of this strategy is of greater importance because it is around these repetitive discourses that Erdoğan, beyond his title of politician, becomes again the organic intellectual of his political movement: He can criticize the territorial planning of a city by defining the norms of constructions that should respect the model of the Seljuks, he orders people to learn the Ottoman language ("Osmanlica"), he announces that the youth should be pious, he pronounces himself on academic platforms by ordering the academic staff to be more sensitive to the struggle of the state against terrorism, he presents himself as a demographic planner by ordering couples to have at least three children, he becomes a historian by questioning some parts of the Treaty of Lausanne, the founding document of the Republic.

If Erdogan during electoral meetings set up a political narrative that highlights particular success story of AK Parti's governments since 2002 through economic and social progresses, New Turkey narrative is also built through political practices that seek to activate the awareness and passions of Turkish voters. These practices are quite varied but the analysis will focus attention on particular examples.

The video clips prepared by the AK Parti are rich enough elements to understand and explain its communicative strategy. The main theme of these videos is to show a radiant and fraternal country's image. In this direction, the first objective is to show the images relevant of all regions of the country, representing the cultural and ethnic diversity. Various local and national symbols are displayed in a refined and touching way. Second, beyond fraternal union, these videos also show the economic development of the country through images that represent the implementation of major projects: bridges, dams, highways, airports, hospitals etc. Indeed, a kind of patriotic nationalism that refers to the traditional values and historical symbols is appearing. It draws attention also to economic growth through a national solidarism. All these images contribute to the symbolization process of the New Turkey narrative.

Apart from these official videos of the AK Parti, there is also another video clips in which the star is particularly Erdogan. During the campaign of the presidential elections in 2014, a video ${ }^{7}$ was displayed for days on TV. At the end of this video, the people from all over the country arrive in Çankaya (the

7 Milletin Adamı, “Cumhur Başkanını Seçiyor”, https://www.youtube.com/watch?v=tvj8XdL-A8M 
Ankara district where the presidential residence is situated), and open the doors of the residence and somehow conquest it, walking with Erdogan. It is important to emphasize that these pictures belong to a fairly strategic political symbolism. The conquest of the presidential residence by the decent people (millet, milli irade) refers to the change in the election procedure of the President of the Republic. Until 2014, it was the National Assembly nominated the president of the republic. While in 2014, the system changed and the election of the President of the Republic is now done by universal suffrage. In the eyes of supporters of the AK Parti, the Presidency of the Republic was as the major fortress Kemalist establishment and the status quo in Turkey. For the military and bureaucracy elite, there was no question of electing a president who was not one of them. So Erdogan's election by the people is perceived as a historical revolution in this video as well as the last fortress of the status quo fell and was captured by the people. Erdogan as being the charismatic and undisputed leader of the masses -which were abandoned by the Old Turkey-, has now become the President of the Republic.

It is possible to consider Erdogan as a charismatic leader whose qualities and virtues are clearly indisputable beside its stable electorate. Erdogan, based on his charismatic authority, constantly creates communication platforms to mobilize the population towards its political vision. Furthermore, touching and guiding the emotions and passions of his electorate are the other pillars of its communicational strategy.

\section{The Role of Pro-AK Parti Medias and Intellectuals}

In fact, this political communication strategy is obviously not limited to Erdoğan's personal practices alone. The media supporting the policies of the AK Parti and Erdoğan plays an important role in disseminating the orientations and visions developed by the government. The proliferation of these pro-AK Parti and pro-Erdoğan media organizations shows us that in the media sector, political power seems to have outpaced the media organizations which make criticisms against AK Parti and Erdoğan's policies. Many pro-government television channels and newspapers have reached millions of spectators and readers over the past decade. While these media organizations are mistaken as "partisans" (yandaş) of the government by the political opposition, it is possible to admit that in the media field the "conservative voice" seems to gain more ground and audience.

So, since the first use of the term New Turkey by Erdogan during a meeting held in Sakarya, in December 2013, the popularization of New Turkey was quickly realized. The supporters of the AK Parti did not wait too long to make 
it a political slogan that immediately invaded the political communication space. Since 2013, New Turkey has often made the headlines and television debates. Many analysts and intellectuals are seeking to conceptualize and give a practical and/or scientific meaning to the term of New Turkey. Pro-AK Parti media and organic intellectuals, in the Gramscian sense of the term, act as médiateurs creating links between the political sphere and public space to legitimize and to make the New Turkey narrative efficient. The mediation role is not exclusive to the media or intellectuals. Political actors themselves, as in the case of Erdogan and other AK Parti members, are working hard to explain the benefits of the "New Turkey" to the Turkish population. However, the contribution of the media and intellectuals fulfills a more strategic and cognitive function.

Second, the support of some analysts and intellectuals is of major importance in legitimizing the New Turkey narrative. In recent years, this support has become more and more explicit. According to opponents of the AK Parti, these actors are considered not as journalists or intellectuals but as "supporters" of the AK Parti and the Erdogan regime. Some of them became members of the AK Parti after the parliamentary elections of 2011 and some of them were candidates for the AK Parti in the 2015 general elections. Indeed, with regard to these examples, the job of political scientist or journalist tends to become a political counselor or political supporting function. Their opinions and political statements tend to become an explicit political support.

\section{The New Turkey Narrative: Reflections in the Social-Cultural and Symbolical Fields}

Another preoccupation of the government and its social partners crystallizes in the field of the history. In this perspective, on the one hand, it is an incessant questioning of the "official" history (Resmi Tarih) written and presented by the official institutions of Old Turkey. On the other hand, this strategy is pursued by the rediscovery of great Turkish history, and by its reinterpretation and reinvention. The questioning of the Treaty of Lausanne or the celebration of historical victories like that of Malazgirt ${ }^{8}$ or that of Kut-ul Amare (until very recently ignored or forgotten by the population) are revealing examples.

8 The Battle of Manzikert was fought between the Byzantine Empire and the Seljuk Empire on 26 August 1071 near Manzikert, theme of Iberia (modern Malazgirt in Muş Province, Turkey). The decisive defeat of the Byzantine army and the capture of the Emperor Romanos IV Diogenes played an important role in undermining Byzantine authority in Anatolia and Armenia, and allowed for the gradual Turkification of Anatolia. Many of the Turks, who had been travelling westward during the 11 th century, saw the victory at Manzikert as an entrance to Asia Minor.

9 The siege of Kut Al Amara (7 December 1915 - 29 April 1916), also known as the first battle of Kut, was the besieging of an 8,000 strong British Army garrison in the town of Kut, 160 kilometres 
The criticisms about the early periods of the Republic directly and / or indirectly attack the foundations of the Kemalist regime. This is a major policy to destabilize the taboos of Old Turkey. Thus, the integration of other facts and other conservative values into the historical narrative becomes possible. It is in this perspective that we must consider the production of TV series by the official state channel (TRT) that encourages the people to rediscover "Abdulhamid II, Ulu Hakan," to rejoice in the heroism of Ertuğrul Gazi ${ }^{10}$ or rejoice in the victory of Kut-ul Amare against the British army. The questioning of the official history and its rediscovery are also consolidated by the publication of history magazines (as Derin Tarih ${ }^{11}$ ) and books praising "unknown" Turkish history. In this context, the aim is to remind the people that it is impossible to make a sudden break between the period of the Ottaman Empire and that of the Republic. The ignorance of the millennial history of the Turks is constantly criticized by Erdoğan. In fact, this approach begins to be part of the cultural hegemonic struggle from the moment that the reinterpretation of history also allows to reestablish bonds of the people with its glorious past but also to restore its relations with Islam. It is therefore a policy to resuscitate traditional and religious values and indeed to redefine national identity. By placing the War of Independence (Kurtuluş Savaşı - Millî Mücadele) among other military victories and Atatürk among other national heroes, the strategy seems quite ambitious in its search for a more encompassing conception of history.

The invention of new symbols and the mobilization of emotions play also a very important role in the creation of New Turkey. Symbols and emotions play perhaps a less explicit but more influential role in the constitution of a new raison d'Etat. Many processes and facts can be observed from this perspective. The failed coup in 2016 and all the events that followed are very revealing in terms of the analysis of politics by symbols and emotions. By pursuing the previous analytical approach concerning history, we can consider that the victory of the people and Erdoğan against the Gulenist coup represents significant political and ideological opportunities. Erdoğan immediately seized this victory, declaring that Turkey is conducting its "second" War of Independence in the face of multiple enemies of the nation such as

south of Baghdad, by the Ottoman Army. In 1915, its population was around 6,500. Following the surrender of the garrison on 29 April 1916, the survivors of the siege were marched to imprisonment at Aleppo, during which many died. Historian Christopher Catherwood has called the siege "the worst defeat of the Allies in World War I". Ten months later, the British Indian Army, consisting almost entirely of newly recruited troops from Western India, conquered Kut, Baghdad and other regions in between in the Fall of Baghdad.

10 The heroic story of Ertugrul Gazi, the father of Osman who founded the Ottoman Empire.

11 www.derintarih.com 
the Gulenist terrorist organization or other foreign enemies. The organization of the annual celebrations of July 15, 2016 (officially recognized as the National Day of Democracy and the Homage to Martyrs) gathering thousands of citizens, the construction of monuments on behalf of the martyrs of July 15 , the establishment of symposiums and literary contests for its commemoration certainly play a prominent role in building a reconsidered national identity. Symbolization can be seen in other modes of political action. During the reception of foreign political representatives at the new presidential palace in Ankara, part of the protocol is constituted by the display of traditional military clothes worn by warriors representing all the Turkish armies existed throughout history. The rediscovery of the "great" Ottoman-Turkish history thus reappears. Another sports activity, called the Etnospor festival organized by Turkey and Kazakhstan, takes place every year in Istanbul. The goal is to set up competitions in traditional Turkish sports. These festivities have managed to get the attention and interest of thousands of spectators and participants since 2016. It is interesting to see a serious and ambitious work for the revaluation of the "tradition" against the prevailing orientations and values of the Old Turkey. Another important activity is that of TEKNOFEST since 2018. The TEKNOFEST (Aerospace and Technological Festival) is organized by the Turkish Technology Team Foundation to showcase Turkey's rapid advances in technology and to promote technology advances as a national cause. TEKNOFEST aims to promote and support national initiatives in various technological sectors, especially in that of military industry.

Yanow (1995) contends that places and physical space policy tell stories. The "New Turkey" is emerging also around big sophisticated construction projects of AK Parti and Erdogan. Firstly, we can mention the construction of the Presidential Palace in 2014. Until Erdogan's election as President of the Republic in 2014, the presidents resided in Çankaya. In 2012, Erdogan has started the construction of the new presidential palace in Ankara. The Project was achieved in 2014. The objective of Erdogan was to build a great presidential center which would be worthy of the greatness of the "New Turkey". Moreover, Erdogan said recently that the presidential palace will not be named as such but as "Cumhurbaskanligi Kulliyesi". The Kulliye -Arabic term equaling to English "collection"-, in the Ottoman period, were as centers gathering mosques, bazaars, libraries, schools, bathhouses, the eating houses, and tombs. Indeed, this appellation is still a strong symbolism that makes a resonance in the Turkish conservatist imaginary. Erdogan pursues its strategy to touching the emotions through the use of such connotations, symbolizing a significant return to the Ottoman tradition. Futhermore, the 
implementation of other big construction projects in the sectors of transport and of infrastructure reflects the ambitions of the New Turkey. The construction of the third bridge over the Bosphorus (Yavuz Sultan Selim Köprüsü), the construction of the Great Çamlica Mosque in İstanbul, the construction of the new international airport of Istanbul or the Istanbul International Financial Center's project are the most significant examples of these sophisticated projects. These constructions are being presented as projects that would accentuate the economic development of the country and which would place Turkey among the most powerful countries int the world. All of it must be considered as social and cultural aspects of the New Turkey narrative against the prevailing orientations and values of the Old Turkey. Many other initiatives in those fields could be presented in another work, by a more detailed way.

\section{Conclusion}

The AK Parti and Erdoğan are governing the country since 2002. Since the governments of Adnan Menderes and the Democratic Party (1950-1960), this term of government has been a record in Turkish democracy. Indeed, it is possible to admit that winning all general elections since 2002 can be considered as a great success. This success is based on various political, economic and social achievements made by Erdoğan and the AK Parti. The charismatic leader and his party still retain great popular support. However, the AK Parti has always been searching for a political-ideological identity since the foundation of the party. We can go back to the declaration of the ideological profile of the party as "democratic conservative" (Muhafazakâr Demokrat) during the election campaign in 2002. Certainly, in a political context where the legitimacy of the AK Parti constantly challenged itself by the status quo, this research was not meaningless. During the first decade of their rule, the importance given to democratic values and reforms and to the process of joining the European Union as well as to "good" relations with the Western world have certainly strengthened the legitimacy of the AK Parti towards a large part of Turkish society but also towards the international community. The good economic performance of the country for a long period has also been used to produce a significant consent from the population. AK Parti and Erdoğan have chosen to conceptualize and emphasize this whole period of democratic advancement and economic growth as the emergence of a "new" Turkey. The questioning of the "past" ( Old Turkey) and the stabilization of the "present time" with the promotion of democratic and economic progress constituted the first phase of the construction of this narrative. During this first period of AK Parti governments, the main objective was to overturn the military tutelage and the 
politico-administrative status quo. Indeed, the adoption of the presidential system in 2017, and the election of Erdoğan as President of the Republic were the major blow against the Kemalist status quo. However, the "conquest" of political and institutional power does not mean the victory of the hegemonic struggle in the social and cultural fields. If this "New Turkey" is to have a "glorious" future with ambitious economic and social goals, it must also acquire an ideological vision that has the power to produce consent and legitimacy in order to gather different components of the society and guide them towards this future. The failed coup of July 15 presented a great opportunity for the AK Parti and Erdoğan to move in this direction.

While New Turkey is considered as a narrative or as the premise of an ideology, it represents both deficiencies and assets to achieve this goal. First, the economic and international contexts are factors that destabilize the government's positioning and its political discourse. Also, depending on the political and electoral opportunities offered by the presidential system, the capacity of the various components of the political opposition to form a strong alliance is growing. The success of Ekrem İmamoğlu, candidate of the alliance formed by CHP-İyi Parti (Millet İttifakı (Nation's Alliance, implicitly supported by the pro-Kurdish party, HDP) in the last municipal elections of Istanbul in June 2019 is quite revealing on the recomposition of new electoral strategies. In this perspective, the political opposition has been more organized than ever since 2002. How to expand the audience and the impact of the New Turkey narrative in these new conditions? A question that AK Parti's elites have been asking since June 2019... While in the speeches of Erdoğan and Bahçeli, the stigmatization of this alliance formed by different political components continue to grow and strengthen, it seems that achieving this goal will not be easy for Cumhur İttifakı (People's Alliance, AK Parti-MHP).

It is also important to precise the strong sides of the New Turkey narrative beyond the strategies of political competition. In the cultural hegemonic struggle against Old Turkey, it is possible to admit that there is a growing civil society of New Turkey, native and national (Yerli ve Milli) which is slowly advancing to equalize and overcome the secular and kemalist civil society elements. We have tried to present the achievements and investments of the AK Parti in the media sector, in the fields of culture, symbolism and history. Therefore, it is possible to highlight the rise of a hegemonic bloc through the coalition of the AK Parti with the media, conservative intellectuals and various actors working in the social and cultural fields. State resources are now serving a conservative and nationalist civil society. In the medium and 
long term, this situation may reinforce this new hegemonic bloc against the persistent domination of the Old Turkey's elites in social and cultural fields.

On the other hand, we must also focus on another aspect of the New Turkey narrative. It can be seen that the narrative begins to acquire the characteristics of a référentiel global insofar as in many sectors of public policy, sectoral actors begin to adapt the norms, values, instruments and objectives of their sectors to the dominant conceptual referents of New Turkey. It is now possible to see the promotion of Yerli ve Milli as the global frame of reference defining the objectives and instruments of public action in each sector of public policy. In this perspective, many examples can be presented: The production of an automobile by national means and resources, tremendous improvements in the national military industry, the purchase of anti-aircraft (S-400) defense systems by Russia despite the American threats, the development of digital softwares by Turkish technicians and experts... Erdoğan, on every occasion, seeks to guide sectoral actors to adopt the Yerli ve Milli posture and vision. So, if some people question the veracity and strength of New Turkey's narrative, they should only focus on these remarkable changes in public policies.

Indeed, the New Turkey narrative fulfills many political, economic and ideological functions. Politically, around this narrative, it is about the rise of a hegemonic bloc with the coalition established between the conservatives and the nationalists (AK Parti-MHP) against a permanently stigmatized political opposition. At the economic level, it is the promotion of an economic model based more on the usage of national resources and means of production. The objective is to increase national production capacity in every sector to reduce the dependence of the Turkish economy on foreign financial and energy markets. Furthermore, on the ideological level, the New Turkey narrative represents an important potential in terms of remedying the ideological deficit of the AK Parti. In this sense, the narrative contributes to the development of new norms of political action and to the rise of a cultural hegemony while investing particularly in the social, cultural, intellectual and symbolical fields.

Finally, it is necessary to make an important adjustment between our singular analysis and the Gramscian approach of hegemony. Gramsci believes that the working class, before taking the institutional and political power, should first expand its power around the development of a civil society that would support its hegemonic struggle with the bourgeoisie. So the emergence of an "alternative" civil society would precede the acquisition of state 
power. In our case, the situation must be considered according to the political and conjunctural particularities in Turkey. Although the AK Parti came to power in 2002, the latter had to face several coup attempts (Balyoz, Kafes and others), a party closure court trial or popular demonstrations supported by the Army (Cumhuriyet Mitingleri). We can even include the Gulenist failed coup in 2016 or the Gezi protests in 2013. So firstly, the AK Parti, beyond its electoral victories, had to fight to maintain its power. In fact, in a way, for a long time, the AK Parti remained in a defensive and reactionary stance in the face of its adversaries. It is in this perspective of analysis that considering the New Turkey narrative as an "offensive" by the AK Parti takes on all its meaning. While politically, the AK Parti has largely neutralized these opponents over the years, in cultural and social fields, concrete efforts have been made just recently. If the AK Parti and Erdoğan seek to keep and consolidate their political power, it seems that they have to be well aware of the importance of their hegemonic struggle in the social, cultural and ideological fields.

\section{References}

Aslan, A. (2018). Yerli ve Milli Siyaset. İsmail Çağlar ve Ali Aslan (Ed.). in AK Parti’nin 15 Yılı: Toplum. (79-103) SETA Yayınları, İstanbul

Bora, T. ve Gültekingil, M. (Ed.). (2017). Modern Türkiye'de Siyasi Düşünce Cilt 5 - Muhafazakârlık. İstanbul: İletişim Yayınları.

Cole Nicki, L. Ph.D. (2020). What Is Cultural Hegemony? ThoughtCo, Jan. 6, thoughtco. com/cultural-hegemony-3026121.(https://www.thoughtco.com/cultural-hegemony-3026121)

Duran, B. (2017, 9 Eylül). Milli ve Yerli Söyleminin İçini Kim Dolduracak? Sabah.

Durnova, A. ve Zittoun, P. (2013). Les Approches Discursives Des Politiques Publiques. Revue française de science politique, Vol.63, 569-577.

Esayan, M. (2016, 28 Mart) .Yeni Çatımız Yerli ve Milli, Akşam.

Esayan, M. (2018, 17 Şubat). Yerli ve Milli'lik Halkın Korumasındadır. Akşam.

Fischer, F. ve Miller, G. (Ed.) (2007). Handbook of Public Policy Analysis, Theory, Politics and Methods. CRC Press, Taylor and Francis Group.

Hacısalihoğlu, Y. (2017, 2 Eylül). Yerli ve Milli Olmak Nedir? Akşam.

Hajer, M. ve Wagenaar, H. (Ed.). (2003). Deliberative Policy Analysis Understanding Governance in the Network Society. Cambridge: Cambridge University Press.

Jobert, B. ve Muller, P. (1987). L'Etat En Action, Politiques Publiques et Corporatismes. Presses universitaires de France.

Jones, M. ve McBeth, M. (2010). A Narrative Policy Framework: Clear Enough To Be Wrong. The Policy Studies Journal, Vol. 38, No. 2, 329-353.

Kahraman, H.B. (2008). Türk Siyasetinin Yapısal Analizi - I Kavramlar Kuramlar Kurumlar. İstanbul, Agora Kitaplığı. 
Kongar, E. (2016). 21. Yüzyılda Türkiye 2000'li Yıllarda Türkiye’nin Toplumsal Yapısı. İstanbul: Remzi Kitabevi.

Radaelli, C. (2000). Logiques de pouvoir et récits dans les politiques publiques de l'Union européenne. Revue française de science politique, 50 (2), 255-275.

Ricci, F. ve Bramant, J. (Ed.). (1975). Gramsci Dans Le Texte. Editions Sociales, Paris: 1975.

Roe, E. (1994). Narrative Policy Analysis. Durham, Duke University Press.

Schmidt, V. ve Radaelli, C. (2004). Policy Change and Discourse in Europe: Conceptual and Methodological Issues. West European Politics, Vol.27, No.2 (March), 183-210 ISSN 0140-2382 DOI: 10.1080/0140238042000214874 (C) 2004 Taylor \& Francis Ltd.

Stone, D. (1989). Causal Stories and the Formation of Policy Agendas. Political Science Quarterly, Vol. 104, No. 2. Summer, 281-300.

Yanow, D. (1995). Built Space as Story. Policy Studies Journal, September, 407-422 